Frontiers: The Interdisciplinary Journal of Study Abroad

(C) 2020 Kerry Stamp

The work is licensed under the Creative Commons Attribution-NonCommercial-

NoDerivatives 4.0 International License.

Volume 32, Issue 3, pp. 208-211

DOI 10.36366/frontiers.v32i3.585

FORUM

ON EDUCATION

ABROAD

Promoting Inclusion in Education Abroad: A Handbook of Research

and Practice. Barclay Hamir, H. \& Gozik, N. (eds). Sterling,

Virginia: Stylus \& NAFSA (2018). [234 pages].

Kerry Stamp ${ }^{1}$

\title{
Abstract
}

This review of Promoting Inclusion in Education Abroad: A Handbook of Research and Practice celebrates the book as a foundational text for all education abroad professionals as the field continues to grapple with, and increasingly prioritize the improvement of inclusion practices amid a rapidly diversifying student body in higher education. The book is important not only for professionals in the field of international education, but moreover for leaders in higher education who are striving to learn more about strategies for inclusion that are demonstrated to be effective through recent research.

\section{Abstract in Spanish}

Esta revista de Promoviendo la Inclusión en la Educación en el Extranjero: un Manual de Investigación y Práctica celebra el libro como un texto fundamental para todos los profesionales de la educación en el extranjero a medida que el campo continúa priorizando cada vez más la mejora de las prácticas de inclusión mientras el cuerpo estudiantil en la educación superior se diversifica rápidamente. El libro es importante no solo para los profesionales en el campo de la educación internacional, sino también para los líderes en la educación superior que se esfuerzan por aprender más sobre estrategias de inclusión que han demostrado ser efectivas por medio de estudios recientes.

\section{Keywords:}

education abroad; inclusion; inclusive excellence; handbook

1 Vassar College, Poughieepsie, NY, USA 
The call to support diverse student participation in study abroad is not new; while the number of U.S. students participating in study abroad has steadily increased, concern over who is (and is not) studying abroad has also risen. Over the past three decades, the scholarship on this topic has expanded in both volume and scope within professional publications and academic journals alike. Adding an important voice to the conversation, Promoting Inclusion in Education Abroad: A Handbook of Research and Practice, provides the first text for higher education professionals dedicated entirely to this topic. Following a forward written by NAFSA: Association of International Educators Executive Director and CEO, Esther Brimmer, the text is organized into three sections: part one frames the issues and challenges, part two delves into inclusion in study abroad in relation to specific student identity groups, and part three proposes next steps for research and practice.

The first two chapters of the book set the foundational understanding for the reader. In the opening chapter, editors Barclay Hamir and Gozik address the varying ways we talk about diversity, access, inclusion, and underrepresented students in study abroad. A key point in the introduction is the explanation of their conceptual framework. They note that it is importantly guided by the framework of inclusive excellence whereas inclusivity enhances the learning environment for all and is critical for equitable access to education. However, the book also includes discussion of students who are statistically underrepresented in study abroad but may hold higher levels of privilege and power (for example, white male students). In turn, they apply a frame of "inclusion" - as to not undermine the integrity of inclusive excellence framework. In chapter 2, Lopez-McGee, Comp, and Contreras provide important context by presenting the most comprehensive literature review of its time for the topic at hand. It provides a review of the first calls for diversifying study abroad participants, followed by summaries of research by student identity groups. Before the concluding recommendations for next research, it also offers a useful synthesis of pertinent research around the educational outcomes of study abroad.

In part two, scholars and practitioners present new research and lessons learned focusing specifically on eight groups of underrepresented students in study abroad, and/or historically underserved students in higher education. These identity groups are: students of color, first generation students, male students, students with disabilities, community college students, students in the sciences, engineering students, and undocumented students. As the editors acknowledge within the introductory chapter of the book, this does not comprehensively address all groups of students who may be considered to be underrepresented in study abroad or historically underserved in higher education. For example, a next iteration would benefit from including students with diverse religious identities and dedicating space for deeper discussion of 
intersectionality. The breadth of areas covered in this handbook is very commendable, though. These chapters also apply a variety of frameworks and methodologies, ranging from empirical studies with larger scale quantitative inquiry, to small program or institutional level case studies, and lessons learned via mixed methods.

The new research included in part two offers valuable insights from faculty members, practitioner-scholars at higher education institutions, study abroad provider representatives, and leaders in organizations that advocate for equity in study abroad. They explore legislation supporting students with disabilities and undocumented students, provide updates on evolving trends such as the profile of the community college student, examine lessons learned from varying institutional and program level pilot innovations, and more. Multiple studies in this text present new and refined approaches of inquiry to expand our understanding of barriers to students' participation in study abroad as well as strategies for combating them. The compilation of scholarship included in this volume is impressive and via the inclusion of contributors with varying perspectives and roles, brings a useful range of frameworks guiding the research inquiry.

Perhaps this volume is most successful in offering very clear bridges from theory to practice with tangible strategies for professionals to explicitly support inclusion in education abroad. The authors also commonly implore professionals in the field to not only commit to supporting students but to contribute more to furthering the research agenda. This call for a broader commitment, however, comes with undaunting recommendations for professionals to adapt. For example, Holben and Malhotra recommend that professionals incorporate demographic questions including asking whether a student has a disability in surveys for study abroad alumni. By improving institutional data collection in this way, the field can be better informed and able to ascertain correlations between practices, programs, and successes with inclusion in education. Overall, this section underscores the importance of strategies specific for student identity groups at the student level and also offers important lessons to be incorporated at the institutional level.

The third and final part of this book focuses on next directions in practice and research. Andrew Gordon, CEO and Founder of Diversity Abroad, emphasizes the importance of enhancing advocacy from the micro to macro levels of our field. He implores that it is important to dedicate time and attention to sustainability of approaches at each of these levels. Barclay Hamir and Gozik echo this emphasis and conclude with a useful summary of findings from the combined research and lessons presented. Finally, they propose specific pathways forward for research. In order to contribute most broadly to progress with inclusion in education abroad, this information is just as important for readers to consider. 
Barclay Hamir and Gozik, and the many contributors have developed a strong foundation for continued growth of research focused on sustaining inclusive excellence in education abroad. It is an essential read for international education professionals, providing a practical and research-grounded guide for promoting access and inclusion. However, as the research demonstrates, sustainable and impactful change must happen at all levels. Promoting Inclusion in Education Abroad: A Handbook of Research and Practice effectively frames inclusion in education abroad as an important issue in higher education at large. Instead of viewing this issue as a study abroad problem about diversity, it should be viewed more broadly as a serious diversity and inclusion issue that presents itself in the context of study abroad - and as a challenge for higher education to address as a whole. To move forward with a systemic level of improvement in inclusion in education abroad, I highly recommend that international education professionals share this text with colleagues in, but also far beyond, the study abroad office. Senior level administrators, faculty, and other stakeholders alike will benefit from the important insights of this foundational text.

\section{Author Biography}

Kerry Stamp is the Director of International Programs at Vassar College. Ms. Stamp's research currently focuses on institutional processes that impact inclusion in education abroad. She is a 2015 award winner of the Innovation in Education Abroad Research Grant; her project piloted a study examining offices of education abroad, and the ways each incorporated considerations of access and inclusion into their study abroad program development and approval processes. Her publications to date address other topics including ethical international service learning and the state of study abroad in the discipline of Public Affairs. 